\title{
Water Allocation Efforts with Water Balance Analysis in the Jatiroto Sub-Watershed and Asem Sub Watershed, Lumajang Districts
}

(Upaya Alokasi Air Sebagai Antisipasi Kekeringan Berbasis Neraca Air di Wilayah Sub DAS

\author{
Asem-Tekung-Jatiroto Kabupaten Lumajang) \\ Gunawan Eko Prihantono, Gusfan Halik*), Entin Hidayah \\ Jurusan Teknik Sipil, Fakultas Teknik, Universitas Jember \\ Jl. Kalimantan 37, Jember 68121
}

\section{ABSTRACT}

Currently, water demand is increasing, both domestic, industrial and agricultural water needs. However, the increase in water demand is not due to an increase in the water availability due to changes in land use and other factors that pose a threat to increased exploitation of water resources. So it is necessary to analyze and evaluate the water needs to anticipate the impact of drought in the Asem-Tekung-Jatirowo sub watersheds. The calculation of water supply and water demand can be carried out using the water balance method, assisted by the WEAP (Evaporation and Water Planning) program, through data integration of streamflow analysis and water user in the river reach. The results showed that the sub-watershed area showed a deficit of water in 2013, with the Jatiroto region having the highest air deficit of 1.58 million $\mathrm{m} 3$ or $44.2 \%$. Based on this analysis, urgently needed a recommendation of drought anticipation strategies these are planting patterns to adjust condition of water supply, storage of water reserves, conservation of critical land, and repair of channels that are at risk of water seepage.

Saat ini kebutuhan air semakin meningkat, baik kebutuhan air domestik, industri maupun kebutuhan air pertanian. Namun peningkatan kebutuhan air tersebut tidak seiring dengan peningkatan ketersediaan air akibat adanya perubahan tata guna lahan dan faktor lain yang menjadi ancaman terjadinya peningkatan eksploitasi bagi sumber daya air. Maka diperlukan analisis dan evaluasi ketersediaan air terhadap kebutuhan air sebagai upaya untuk mengantisipasi dampak kekeringan di wilayah Sub DAS Asem-TekungJatiroto. Besar ketersediaan air dan kebutuhan air dapat dilakukan dengan metode neraca air, dengan program bantu WEAP (Water Evauation and Planning) melalui integrasi data ketersediaan air berupa analisis debit aliran dan data pengguna air di jaringan sungai tersebut. Hasil penelitian menunjukkan bahwa wilayah Sub DAS tersebut menunjukan terjadinya defisit ketersediaan air pada tahun 2013, dengan wilayah Jatiroto yang memiliki defisit air tertinggi sebesar sebesar 1,58 juta m3 atau 44,2\%. Berdasarkan analisis tersebut maka direkomendasikan strategi antisipasi kekeringan berupa rekomendasi pola tata tanam menyesuaikan ketersediaan air, penyimpanan cadangan air, konservasi lahan kritis, dan perbaikan saluran yang beresiko terjadi rembesan

Keywords: Drought, water balance, anticipation, WEAP.

*)Corresponding author:

Gusfan Halik

E-mail: gusfan.teknik@unej.ac.id

\section{PENDAHULUAN}

Kekeringan merupakan bencana alam yang terjadinya cukup sering dan kerap kali menimbulkan kerugian. Kekeringan bersifat perlahan, berakumulasi, dan sulit diketahui kapan mulai dan berakhirnya serta berapa lama terjadinya [1]. Pengelolaan sumber daya air memerlukan informasi yang jelas mengenai kekeringan, terkait dengan awal, akhir dan durasi kekeringan, serta tingkat keparahan kekeringan, dan juga prediksi akan terjadinya bencana kekeringan [2]. Dampak musim kemarau dengan rentang lama menyebabkan cadangan air tanah akan menurun karena adanya evaporasi, transpirasi, maupun penggunaan lain oleh manusia. Terjadi defisir air yang terjadi antara 1-3 kali dalam setahun engan durasi 5-46 
hari tiap kejadian di daerah penelitian Rowotamtu, hal ini dilihat dari ambang batas debit pada kuantil 90\% pada 15 Daerah Aliran Sungai (DAS) di Jawa Timur [3], begitu halnya di Kabupaten Lumajang.

Berdasarkan permasalahan diatas maka upaya pengelolaan sumberdaya air melalui perencanaan, pelaksanaan, pemantauan dan evaluasi penyelenggaraan konservasi, pendayagunaan air, dan pengendalian daya rusaknya air penting untuk dilaksanakan. Terkait dengan ancaman bencana kekeringan, maka perlu dilakukan analisis kekeringan untuk mengevaluasi bencana kekeringan yang telah terjadi, sebagai bahan perencanaan dalam mengelola sumber daya air strategis melalui Pola dan Rencana Pengelolaan Sumber Daya Air serta Rencana Alokasi Air Tahunan [2].

Analisis dan evaluasi kondisi hidrologi pada suatu DAS dapat dilakukan melalui model-model tertentu baik menggunakan neraca air atau menggunakan bantuan program pemodelan hidrologi, salah satunya adalah program WEAP (Water Evaluation and Planning) [4]. Dengan program ini, dapat diketahui apakah sumber air yang tersedia mencukupi atau tidak dalam memenuhi permintaan air yang meningkat di daerah aliran sungai seperti penelitian yang dilakukan di DAS Arror, Kenya [5], dan khususnya jika penggunaan air irigasi diperluas, seperti yang dilakukan di Sungai Pungwe, Mozambik [6]. Sehingga dalam penelitian ini dapat dianalisis kondisi ada tidaknya defisit maupun kondisi surplus air tertinggi pada suatu daerah sehingga dapat menjadi acuan dalam pengambilan strategi kebijakan dalam rencana mitigasi kekeringan di suatu daerah.

\section{METODE PENELITIAN}

\section{Lokasi Penelitian}

Penelitian dilakukan di DAS Bondoyudo Kabupaten Lumajang dengan koordinat lokasi $112^{\circ}$ $50^{\prime} 00^{\prime \prime}$ - $113^{\circ} 22^{\prime} 00^{\prime \prime}$ BT dan $7^{\circ} 52^{\prime} 00^{\prime \prime}-8^{\circ} 23^{\prime} 00^{\prime \prime}$ LS, dengan wilayah yang diteliti adalah Sub DAS Asem-Tekung-Jatiroto, yang memanfaatkan aliran Sungai Asem dan Sungai Jatiroto. Secara umum wilayah ini termasuk daerah dataran rendah sehingga masih banyak dimanfaatkan sebagai lahan pertanian seperti padi, palawija dan tebu. Adapun wilayah penelitian ditampilkan pada Gambar 1.

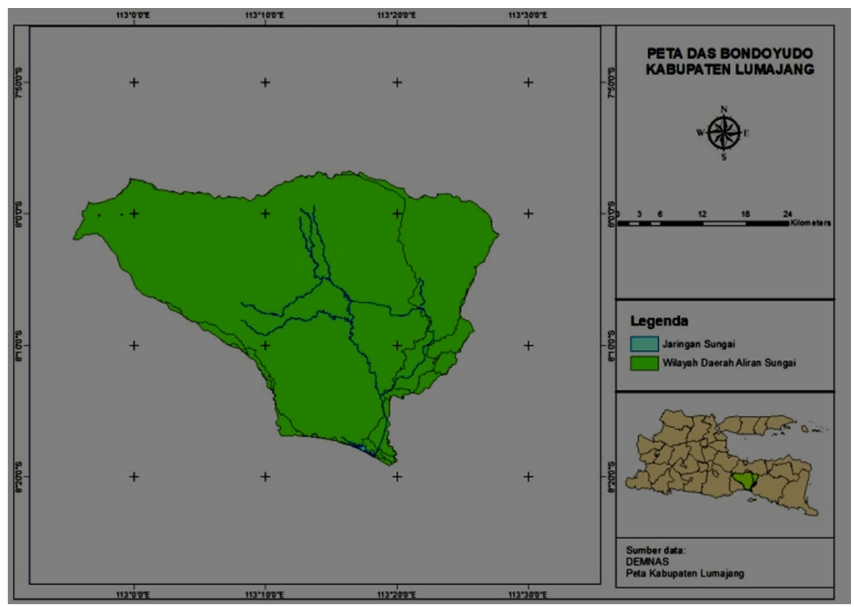

(Sumber: UPT SDA Lumajang, 2021)

Gambar 1. Peta Wilayah Penelitian

\section{Pengumpulan Data}

Jenis dan sumber data yang diperlukan dalam penelitian ini diperoleh dari:

1. Data curah hujan tahun 2010 - 2019, didapatkan dari UPT PSDA-WS Bondoyudo Baru;

2. Data klimatologi tahun 2010 - 2019, didapatkan dari UPT PSDA-WS Bondoyudo-Baru Kab. Lumajang, dengan rincian data yang digunakan yaitu data kelembaban udara, temperatur, besar kecepatan angin, dan lamanya penyinaran matahari;

3. Peta Batas DAS, hasil kelola data dengan Arc GIS yang bersumber dari data DEMNAS dan Peta RBI;

4. Rencana Tata Tanam Global dan data luas lahan yang didapatkan dari Dinas Pekerjaan Umum dan Tata Ruang Lumajang;

5. Data industri pengguna air didapatkan dari UPT. PSDA Kabupaten Lumajang.

\section{Pengelolahan Data \\ Kebutuhan Air Pertanian}

Pertanian sebagai sektor penting yang menunjang ketersediaan pangan. Irigasi untuk pertanian memanfaatkan debit sungai atau sumber air lainnya melalui saluran irigasi sebagai media pengairan dan membagi air untuk tiap lahan [7]. Agar diberikan hasil yang maksimal karena tanaman tumbuh dengan baik, maka kebutuhan air pertanian dihitung berdasarkan jumlah kebutuhan air di suatu tempat [8]. Yang harus dilakukan dalam menghitung kebutuhan air pertanian melalui skema pola tata tanam adalah:

1. Menghitung curah hujan efektif

2. Menghitung besar evapotranspirasi 
3. Parameter kebutuhan pertanian seperti koefisien tanaman, perkolasi, persiapan lahan, penggantian lapisan air [9]

4. Menghitung kebutuhan air bersih di sawah, dengan menambah kebutuhan air konsumtif dengan besar laju perkolasi, penyiapan lahan, dan penggantian lapisan air bila perlu kemudian dikurangi dengan besar curah hujan efektif.

\section{Kebutuhan Air Industri}

Kebutuhan air industri dihitung secara keseluruhan yaitu dari industri yang telah memiliki ijin untuk memanfaatkan air dalam satu wilayah daerah aliran sungai, disesuaikan dengan jumlah riil penggunaan kebutuhan air industri.

\section{Ketersediaan Air}

Ketersediaan air permukaan dengan sumber dari debit aliran Sub DAS Jatiroto - Sub DAS Asem. Besar debit didapatkan dengan melakukan perhitungan debit andalan 80\% yang dihitung berdasarkan data debit intake dari bangunan pengukur. Persamaan untuk menghitung debit andalan adalah sebagai berikut [10]:

$$
P=\frac{m}{n+1} \times 100
$$

Keterangan :

$\mathrm{P}=$ peluang debit $(\%)$,

$\mathrm{m}=$ urutan data debit ke-,

$\mathrm{n}=$ banyak data

\section{Program WEAP Berbasis Neraca Air}

Dengan prinsip kesetimbangan air pada WEAP, maka dilakukan langkah sebagai berikut:

1. Membuat gambar wilayah dan aliran sungai;

2. Membuat skema jaringan sungai dan titik sektor pengguna air;

3. Data masukan: data debit andalan bulanan periode 2010-2019, data kebutuhan air irigasi (luas baku sawah, persentase kebutuhan air tiap periode 10 harian), dan kebutuhan air industry;

4. Menjalankan run program;

5. Output analisis: jumlah kebutuhan air yang meliputi kebutuhan air pertanian dan industri serta jumlah ketersediaan air.

\section{HASIL DAN PEMBAHASAN}

\section{Kebutuhan Air}

Dilakukan perhitungan kebutuhan air untuk kedua sektor, yaitu pertanian dan industri pada tiga sub DAS, yaitu Asem-Tekung-Jatiroto. Hasil perhitungan kebutuhan air pertanian dengan menggunakan pola tata tanam terdapat pada Tabel 1.

Tabel 1. Kebutuhan air pertanian pada tiga Sub DAS

\begin{tabular}{cccc}
\hline \multirow{2}{*}{ Bulan } & \multicolumn{3}{c}{ Kebutuhan air $\left(\mathrm{dm}^{3} / \mathrm{s} / \mathrm{ha}\right)$} \\
\cline { 2 - 4 } & Asem & Tekung & Jatiroto \\
\hline Jan & 0.00 & 0.00 & 0.00 \\
Feb & 0.54 & 0.00 & 0.14 \\
Mar & 6.59 & 0.00 & 4.00 \\
Apr & 4.03 & 0.00 & 4.68 \\
May & 0.69 & 0.00 & 4.30 \\
Jun & 0.81 & 2.43 & 4.49 \\
Jul & 13.11 & 4.72 & 5.59 \\
Aug & 16.75 & 8.11 & 10.50 \\
Sep & 17.11 & 8.77 & 8.96 \\
Oct & 2.36 & 3.02 & 6.20 \\
Nov & 0.00 & 0.00 & 2.68 \\
Dec & 0.00 & 0.00 & 1.66 \\
\hline Total & 61.98 & 27.05 & 53.21 \\
\hline
\end{tabular}

(Sumber: Dokumen Penelitian,2021)

Dari Tabel 1, kebutuhan pertanian memiliki nilai yang bervariasi, hal ini dikarenakan pola tata tanam, hal ini karena pola tanam yang berbeda. Pada wilayah Asem dan Jatiroto, awal masa tanam dimulai pada bulan November periode 1 sedangkan di Tekung awal masa tanam dimulai pada Oktober periode 2. Selain itu, penyebab bervariasinya nilai tersebut dikarenakan oleh faktor besarnya curah hujan efektif yang berbeda tiap bulan dalam satu tahunnya.

Tabel 2 merupakan jumlah kebutuhan industri bulanan. Adapun kebutuhan industri ini hanya ada di wilayah Jatiroto, dan nilai yang tertera pada tabel merupakan jumlah aktual pemanfaatan air industri. Dari tabel 1 yang telah disajikan sebelumnya, terlihat bahwa kebutuhan air pertanian menjadi kebutuhan air utama dan tertinggi pada setiap wilayah.

\section{Ketersediaan Air}

Ketersediaan air didapatkan dari perhitungan debit andalan $80 \%$. Berikut ini disajikan tabel antara curah hujan dan debit andalan sungai. Pengukuran debit dan curah hujan menggunakan alat ukur debit debit sedangkan curah hujan didapatkan dari hasil alat ukur hujan melalui pengamatan stasiun hujan pada setiap wilayah. Data tersebut disajikan pada Gambar 2.

Berdasarkan Gambar 2 menunjukkan bahwa pada bulan Januari sampai dengan bulan Juni curah hujan tinggi dan volume debit aliran sungai juga cukup 
tinggi, sedangkan pada bulan Agustus sampai dengan bulan Oktober terdapat penurunan curah hujan dan penurunan volume debit. Hal ini menunjukkan bahwa curah hujan juga berpengaruh pada debit aliran sungai.

\section{Analisis Neraca Air dengan WEAP}

Neraca air dihitung dengan bantuan program WEAP, dengan menginput nilai yang diketahui dan elah dihitung sebelumnya seperti jumlah kebutuhan air dalam tahunan, nilai persentase kebutuhan per periode, luas lahan, besaran konsumsi dalam setiap tahun untuk memperoleh nilai arus balik (return flow).

Tabel 2. Kebutuhan air industri perbulan

\begin{tabular}{ccccccccccccc}
\hline Bulan & Jan & Feb & Mar & Apr & Mei & Jun & Jul & Ags & Sep & Okt & Nov & Dec \\
\hline $\begin{array}{c}\text { Kebutuhan air } \\
\left(\mathrm{m}^{3} / \mathrm{s}\right)\end{array}$ & 0.67 & 0.67 & 0.67 & 0.67 & 3.67 & 3.67 & 3.67 & 3.67 & 3.67 & 3.67 & 0.67 & 0.67 \\
\hline
\end{tabular}

(Sumber: Dokumen Penelitian, 2021)

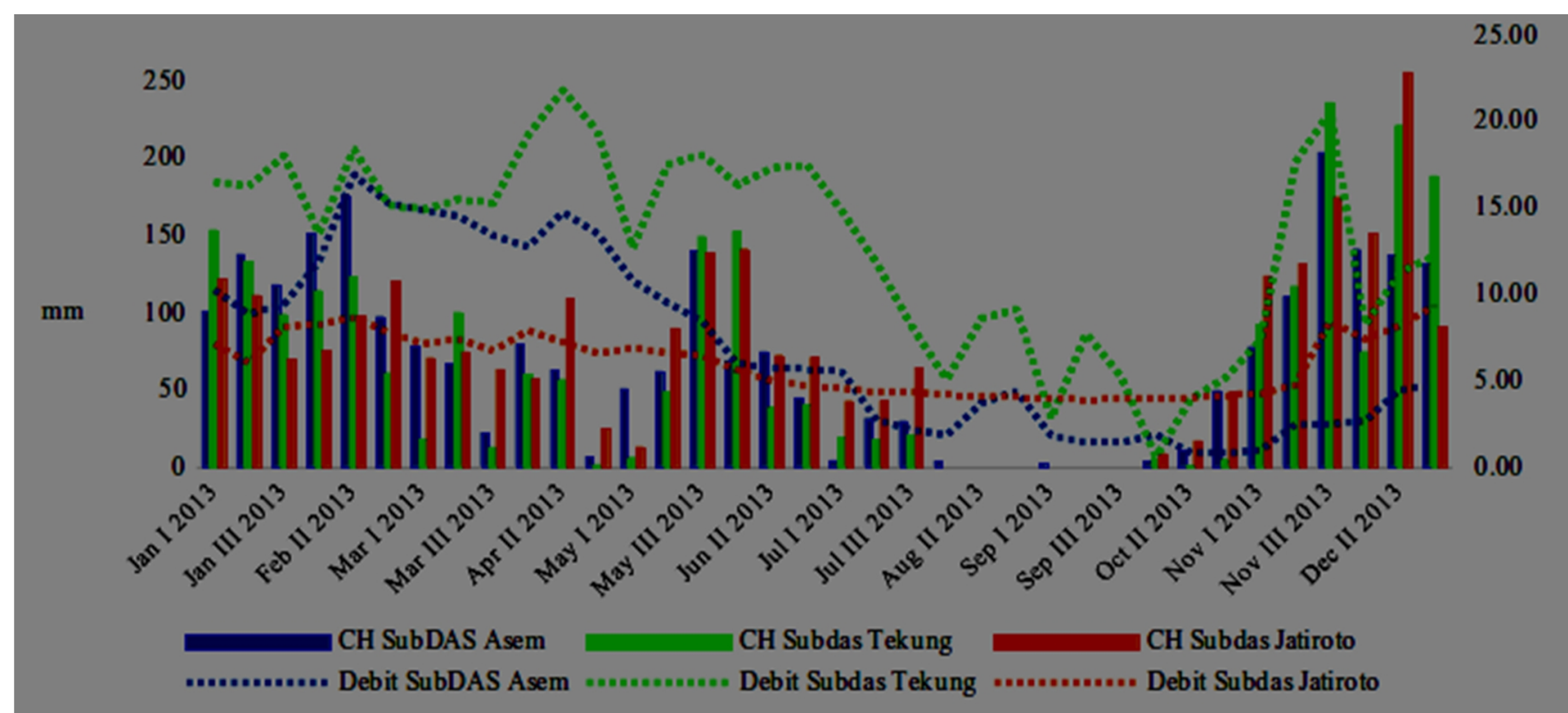

(Sumber: Dokumen Penelitian, 2021)

Gambar 2. Grafik curah hujan dan debit andalan sungai

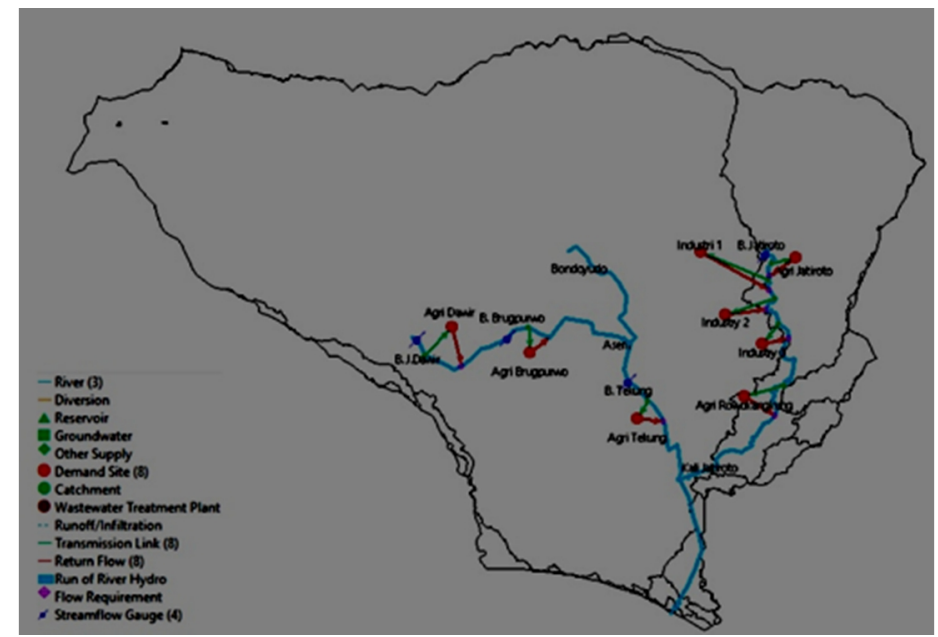

(Sumber: Dokumen Penelitian, 2021)

Gambar 3. Skema jaringan sungai dan titik kebutuhan air pada WEAP 


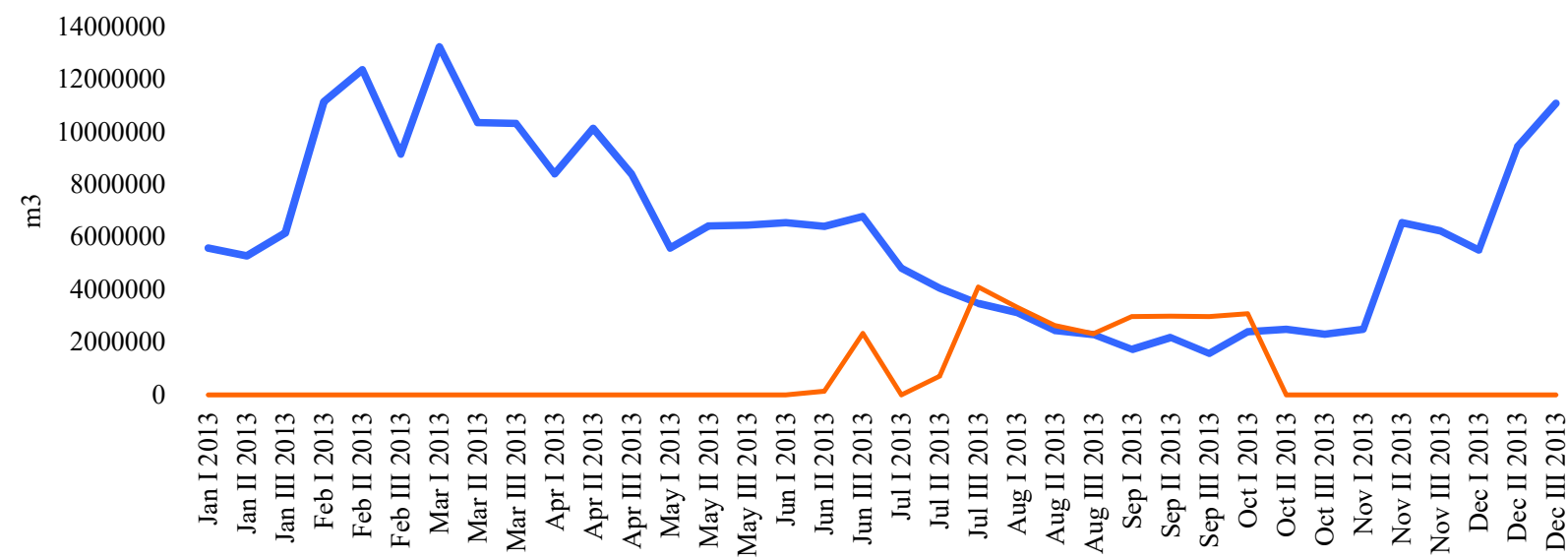

$\longrightarrow$ Debit Ketersediaan $\longrightarrow$ Debit Kebutuhan

(Sumber: Dokumen Penelitian, 2021)

Gambar 4. Kebutuhan dan ketersediaan air Sub DAS Asem

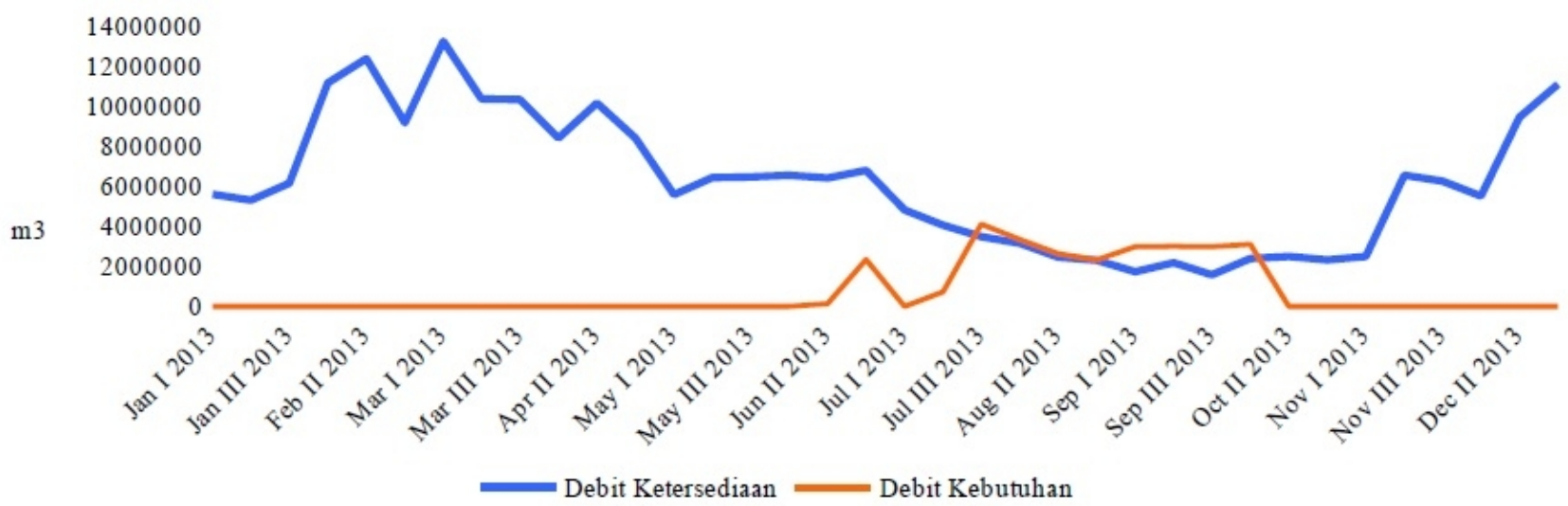

Sumber: Dokumen Penelitian, 2021)

Gambar 5. Kebutuhan dan ketersediaan air Sub DAS Tekung

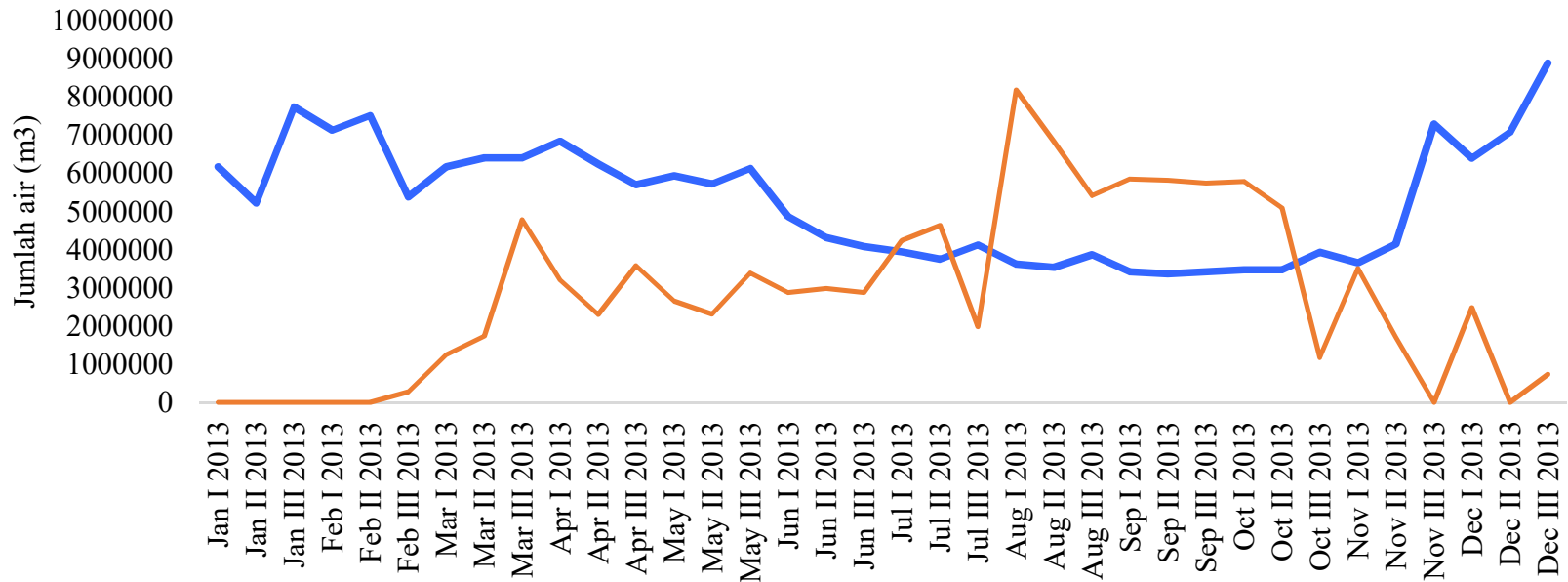

$\longrightarrow$ Debit Ketersediaan $\longrightarrow$ Debit Kebutuhan

Sumber: Dokumen Penelitian, 2021)

Gambar 6. Kebutuhan dan ketersediaan air Sub DAS Jatiroto 
Gambar 4 merupakan grafik perbandingan kebutuhan dan ketersediaan air dari Sub DAS Asem. Sebagian besar debit kebutuhan sudah dapat dicukupi oleh debit yang tersedia, sedangkan pada bulan November periode I kebutuhan air melebihi dari debit ketersediaan. Dari ketidakcukupan tersebut maka perlu dilakukan langkah antisipasi. Selain itu, hasil keluaran WEAP berupa coverage (\%) perlu dibandingkan terhadap intensitas tanam yang dihasilkan dari kondisi di lapangan yang terdapat pada Tabel 3.

Tabel 3. Perbandingan Intensitas Tanam dan Coverage sub DAS Asem

\begin{tabular}{ccc}
\hline Masa Tanam & Intensitas Tanam (\%) & Coverage WEAP (\%) \\
\hline MK I (Mar-Jun) & 88,5 & 100,0 \\
MK II (Jul-Okt) & 84,2 & 91,8 \\
MH (Nov-Feb) & 100,0 & 100,0 \\
\hline
\end{tabular}

Sumber: Dokumen Penelitian, 2021)

Dari Tabel 3, diketahui hasil coverage WEAP memiliki nilai yang lebih tinggi daripada intensitas tanam. Ini berarti debit andalan di periode tersebut mencukupi kebutuhan air pertanian di periode yang sama.

Gambar 5 adalah grafik perbandingan kebutuhan dan ketersediaan air dari Sub DAS Tekung. Pada bulan Januari sampai dengan bulan Juni debit kebutuhan sudah dapat dicukupi oleh debit yang tersedia, sedangkan pada bulan Juli sampai dengan bulan Oktober kebutuhan air melebihi dari debit ketersediaan, maka debit kebutuhan tidak dapat dicukupi oleh debit yang tersedia, hal ini menandakan bahwa pada periode tersebut terjadi defisit ketersediaan air.

Berdasarkan Gambar 6, dapat dilihat bahwa sebagian besar debit ketersediaan mampu memenuhi jumlah kebutuhan air yang ada. Kebutuhan yang ada Namun pada bulan - bulan musim kemarau yaitu Juli hingga Oktober debit yang tersedia belum dapat memenuhi kebutuhan air, hal ini yang menyebabkan adanya defisit air pada bulan tersebut sehingga akan memunculkan potensi kekeringan. Adapun defisit tertinggi terdapat pada bulan Agustus yaitu sebesar $86,2 \%$

Dari 3 wilayah Sub DAS, Asem, Tekung dan Jatiroto, dapat dilihat bahwa kebutuhan tertinggi terdapat pada wilayah Jatiroto karena wilayah tersebut memiliki luas lahan pertanian terbesar 4337 ha yang sebagian besar ditanami tebu, sedangkan Asem 2182 ha dan Tekung sebesar 1920 ha. Adapun berdasarkan Gambar 4, 5 dan 6 didapatkan nilai surplus ketersediaan air yang tertinggi adalah Sub DAS Asem dengan nilai surplus rata-rata sebesar 80,31\%. Sedangkan Sub DAS yang memiliki nilai defisit tertinggi adalah Sub DAS Jatiroto dengan nilai defisit rata-rata sebesar $44,2 \%$.

Tabel 4. Perbandingan Intensitas Tanam dan Coverage sub DAS Tekung

\begin{tabular}{ccc}
\hline Masa Tanam & Intensitas Tanam (\%) & Coverage WEAP (\%) \\
\hline MK I (Mar-Jun) & 94,7 & 100,0 \\
MK II (Jul-Okt) & 98,3 & 99,8 \\
MH (Nov-Feb) & 100,0 & 100,0 \\
\hline \multicolumn{2}{l}{ Sumber: Dokumen Penelitian, 2021) }
\end{tabular}

Dari Tabel 4, diketahui hasil coverage WEAP pada sub DAS Tekung memiliki nilai yang lebih tinggi daripada intensitas tanam di wilayah tersebut. Ini berarti debit andalan di periode tersebut mencukupi kebutuhan air pertanian di periode yang sama.

\section{Skenario dengan Menggunakan WEAP}

Skenario yang dimaksud adalah dengan memaju atau masa tanam yang menyesuaikan keadaan ketersediaan air. Dengan cara tersebut, maka dicari kebutuhan air yang optimal. Selanjutnya diinput dalam WEAP sehingga dihasilkan nilai coverage yang paling optimal.

\section{Skenario 1: Memajukan waktu awal masa tanam}

Skenario dilakukan untuk wilayah 3 sub DAS, di antaranya Sub DAS Asem, Sub DAS Tekung dan Sub DAS Jatiroto. Skenario 1 dilakukan dengan membuat masa tanam menjadi lebih awal daripada RT'TG.

Tabel 5. Perbandingan coverage WEAP dan skenario 1 sub DAS Asem

\begin{tabular}{ccc}
\hline Masa Tanam & Intensitas Tanam (\%) & Coverage WEAP (\%) \\
\hline MK I (Mar-Jun) & 100,0 & 100,0 \\
MK II (Jul-Okt) & 89,63 & 93,76 \\
MH (Nov-Feb) & 100,0 & 100,0
\end{tabular}

Sumber: Dokumen Penelitian, 2021)

Untuk sub DAS Asem, dari masa tanam November 2 menjadi November 1. Didapatkan besar coverage seperti pada Tabel 5. Hasil coverage setelah dilakukan 
skenario menjadi lebih optimal sebesar 4,13\% daripada sebelum dilakukan pengembangan skenario.

Dari perhitungan WEAP didapatkan hasil coverage (kebutuhan tercukupi) di Sub DAS Tekung seperti yang ditunjukkan Tabel 6.

Tabel 6. Perbandingan coverage WEAP dan skenario 1 sub DAS Tekung

\begin{tabular}{ccc}
\hline Masa Tanam & Intensitas Tanam (\%) & Coverage WEAP (\%) \\
\hline MK I (Mar-Jun) & 100,0 & 100,0 \\
MK II (Jul-Okt) & 97,5 & 99,9 \\
MH (Nov-Feb) & 100,0 & 100,0
\end{tabular}

Sumber: Dokumen Penelitian, 2021)

Untuk sub DAS Tekung. Pada sub DAS Tekung masa tanam dimulai pada bulan Oktober periode 2 . Kemudian dilakukan perhitungan dengan memajukan masa tanam menjadi Oktober 1. Setelah dilakukan skenario, coverage meningkat menjadi 2,4\%.Kemudian untuk Sub DAS Jatiroto, masa tanam dilakukan pada bulan November periode 1 kemudian dilakukan perhitungan dengan percobaan dengan memajukan masa tanam menjadi Oktober periode 2. Tabel 7 merupakan hasil coverage setelah optimasi.

Tabel 7. Perbandingan coverage WEAP dan skenario 1 sub DAS Jatiroto

\begin{tabular}{ccc}
\hline Masa Tanam & Intensitas Tanam (\%) & Coverage WEAP $(\%)$ \\
\hline MK I (Mar-Jun) & 100,0 & 100,0 \\
MK II (Jul-Okt) & 100,0 & 100,0 \\
MH (Nov-Feb) & 89,4 & 89,7 \\
\hline
\end{tabular}

Sumber: Dokumen Penelitian, 2021)

\section{Skenario 2: Memundurkan waktu awal masa tanam}

Pada sub DAS Asem awal masa tanam dimulai pada November periode 2, kemudian dilakukan perubahan awal masa tanam menjadi November 3. Dari perhitungan WEAP didapatkan hasil coverage seperti yang ditunjukkan Tabel 8.

Tabel 8. Perbandingan coverage WEAP dan skenario 2 sub DAS Asem

\begin{tabular}{ccc}
\hline Masa Tanam & Intensitas Tanam (\%) & Coverage WEAP (\%) \\
\hline MK I (Mar-Jun) & 100,0 & 100,0 \\
MK II (Jul-Okt) & 89,63 & 97,5 \\
MH (Nov-Feb) & 100,0 & 100,0 \\
\hline
\end{tabular}

Sumber: Dokumen Penelitian, 2021)

Selanjutnya dilakukan skenario pada Sub DAS Tekung, hasil coverage ditunjukkan pada Tabel 9.

Tabel 9. Perbandingan coverage WEAP dan skenario 2 sub DAS Tekung

\begin{tabular}{ccc}
\hline Masa Tanam & Intensitas Tanam (\%) & Coverage WEAP (\%) \\
\hline MK I (Mar-Jun) & 100,0 & 100,0 \\
MK II (Jul-Okt) & 87,61 & 91,66 \\
MH (Nov-Feb) & 100,0 & 100,0 \\
\hline \multicolumn{2}{l}{ Sumber: Dokumen Penelitian, 2021) }
\end{tabular}

Untuk sub DAS Tekung. Pada sub DAS Tekung masa tanam dimulai pada bulan Oktober 2. Kemudian dilakukan perhitungan dengan memajukan masa tanam menjadi Oktober 3. Setelah dilakukan skenario, coverage meningkat menjadi 4,06\% daripada sebelum skenario.

Kemudian untuk Sub DAS Jatiroto, dilakukan skenario untuk memundurkan awal masa tanam. Hasil coverage sebelum dan sesudah skenario terdapat pada Tabel 10.

Tabel 10. Perbandingan coverage WEAP dan skenario 2 sub DAS Jatiroto

\begin{tabular}{ccc}
\hline Masa Tanam & Intensitas Tanam (\%) & Coverage WEAP (\%) \\
\hline MK I (Mar-Jun) & 100,0 & 100,0 \\
MK II (Jul-Okt) & 100,0 & 97,5 \\
MH (Nov-Feb) & 89,4 & 89,1 \\
\hline
\end{tabular}

Sumber: Dokumen Penelitian, 2021)

Sub DAS Jatiroto memiliki awal masa tanam di Bulan November periode 1, apabila dilakukan skenario dengan memundurkan masa tanam di November 2, maka terjadi penurunan nilai coverage dengan kisaran angka 0,3 - 2,5\%. Sehingga dipilih yang paling optimal adalah pada bulan November 1 .

\section{KESIMPULAN}

Berdasarkan hasil analisis yang dilakukan dapat diketahui bahwa pada Sub DAS Asem-Tekung-Jatiroto mengalami defisit terutama pada musim tanam MK II (Juli-Okt). Guna memenuhi ketersediaan air perlu diupayakan pergeseran masa tanam agar kebutuhan dan ketersediaan air serta jangkauan pelayanan dapat dicukupi serta ditingkatkan, adapun upaya perubahan masa tanam yang dilakukan pada Sub DAS Asem 
adalah menjadi bulan November periode 1, Sub DAS Tekung pada masa tanam pada bulan Oktober periode 3, Sub DAS Jatiroto pada Oktober periode 2. Selain itu diperlukan upaya dengan membangun reservoir yang dapat menampung air dikala debit berlebih pada sub DAS yang terjadi kelebihan air, di kala melakukan kegiatan pemeliharaan terhadap keberadaan saluran dan bangunan irigasi secara rutin guna mengurangi kehilangan air.

\section{DAFTAR PUSTAKA}

[1] K. Adam and I. Rudiarto, "Kajian Tingkat Kerentanan Bencana Kekeringan Pertanian Di Kabupaten Demak," J. Tek. Sipil dan Perenc., vol. 19, no. 1, pp. 916, 2017.

[2] Puslitbang Sumber Daya Air, "Naskah Ilmiah Analisa Kekeringan Untuk Pengelolaan Sumber Daya Air," Output Kegiat. Balitbang PUPR, no. 022, 2014.

[3] Indarto, S. Wahyuningsih, M. Pudjojono, H. Ahmad, and Y. Ahmad, "Studi Pendahuluan tentang Penerapan Metode Ambang Bertingkat untuk Analisis Kekeringan Hidrologi pada 15 DAS di Wilayah Jawa Timur," J. Agroteknologi, vol. 08, no. 02, pp. 112-121, 2014.

[4] D. Yates, J. Sieber, D. Purkey, and A. Huber-Lee, "WEAP21 - A demand-, priority-, and preferencedriven water planning model. Part 1: Model characteristics," Water Int., 2005.

[5] C. Chebet, E. C. Kipkorir, and V. A. O. Odenyo, "Assessment of water demand dynamics in arror watershed in Elgeyo Marakwet county, Kenya," J. Water Clim. Chang., vol. 10, no. 3, pp. 642-657, 2019.

[6] Y. Nordström, "Water Availability Challenges in Mozambique - Implications to the Nexus," 2019.

[7] R. Gandakoesoemah, Irigasi. Sumur Bandung, Bandung, 1969.

[8] P. Didik, "Evaluasi Ketersediaan Air Permukaan Untuk Irigasi Pertanian Kecamatan Prambanan Kabupaten Sleman Daerah Istimewa Yogyakarta," Universitas Gadjah Mada, Yogyakarta, 2005.

[9] Direktorat Jenderal Sumber Daya Air, Standar Perencanaan Irigasi. Kriteria Perencanaan Bagian Saluran Kp-03. 2013.

[10] L. Montarcih, Hidrologi Teknik Terapan. 2009. 